\title{
PENGARUH MODAL BUDAYA, TINGKAT PENDIDIKAN ORANG TUA DAN TINGKAT PENDAPATAN ORANG TUA TERHADAP PRESTASI AKADEMIK PADA MAHASISWA FAKULTAS EKONOMI UNIVERSITAS NEGERI JAKARTA
}

\author{
Drs. Henry Eryanto, MM \\ (Dosen Fakultas Ekonomi UNJ) \\ Darma Rika S., S.Pd., M.Si. \\ (Dosen Fakultas Ekonomi UNJ)
}

\begin{abstract}
This research was aimed at describing the effect of cultural capital, education level of parents and income level of parents to academic achievement. In this research, the analysis use qualitative and quantitative. Qualitative analysis described in descriptive about cultural capital, education level of parents and income level of parents to academic achievement. The quantitative analysis used Logistic Regression. The Regression of research results show that: (1) cultural capital has a positive influence to academic achievement and the effect statistically significant. (2) education level of parents has a positive influence to academic achievement and the effect statistically significant. (3) income level of parents has a positive influence to academic achievement and the effect statistically significant.
\end{abstract}

\section{PENDAHULUAN}

Setelah memasuki 11 tahun pada era milenium kedua dimana tingkat persaingan semakin tinggi, negara Indonesia dituntut untuk mampu beradaptasi dan bersaing dengan negara-negara lain. Dalam menghadapi tantangan tersebut dibutuhkan sumber daya manusia yang berkualitas. Salah satu upaya untuk meningkatkan kualitas sumber daya manusia adalah melalui pendidikan. kegiatan yang

perkembangan

\section{Pendidikan}

merupakan mengatur manusia secara terarah untuk menjadi manusia yang baik dan berguna. Salah satu ukuran keberhasilan pendidikan adalah prestasi akademik dari anak didik. Anak didik dalam hal ini mahasiswa merupakan remaja yang masih dalam masa transisi dan penyesuaian. Remaja pada umumnya tidak terlepas dari masalah-masalah yang dapat mempengaruhi prestasi akademiknya.

Prestasi akademik berhubungan dengan bagaimana anak didik mempunyai kepercayaan diri atas kemampuannya untuk menentukan dan melaksanankan berbagai macam tugas serta bisa menampilkan performa 
perilaku untuk menyelesaikan tugas tertentu dengan baik dan efektif kepercayaan dirinya, kemampuan dirinya tersebut disebut dengan efikasi diri (Self efficacy).

Dalam hal tingkah laku terhadap dirinya sendiri individu akan memilih menyelesaikan tugas-tugas tertentu dengan tuntas dan baik disesuaikan dengan kemampuan yang dimilikinya. Lingkungan belajar yang menyenangkan, tidak mengancam, memberi semangat, dan sikap optimisme bagi siswa dalam belajar, cenderung akan mendorong seseorang untuk belajar. Hal ini berarti efikasi diri mempunyai peranan dalam menentukan kualitas dan kuantitas belajar mahasiswa. Realita yang terjadi kecenderungan efikasi diri mahasiswa rendah sehingga prestasi akademik mereka pun rendah.

Dalam proses belajar mengajar motivasi juga mempunyai peranannya terhadap prestasi akademik. Karena dengan adanya motivasi dapat menumbuhkan minat belajar anak didik. Bagi anak didik yang memiliki motivasi yang kuat akan mempunyai keinginan untuk melaksanakan kegiatan belajar mengajar. Sehingga boleh jadi anak didik yang memiliki intelegensi yang cukup tinggi menjadi gagal karena kekurangan motivasi, sebab hasil belajar itu akan optimal bila terdapat motivasi yang tepat. Karenanya, bila anak didik mengalami kegagalan dalam belajar, hal ini bukanlah semata-mata kesalahan mereka, tetapi mungkin saja pendidik tidak berhasil dalam membangkitkan motivasi anak didik.

Modal budaya menyangkut kegiatan partisipasi dalam kegiatankegiatan budaya, iklim membaca, dan kegiatan ekstrakurikuler yang dapat meningkatkan prestasi akademik pada mahasiswa. Kegiatan-kegiatan budaya dalam hal ini misalnya mengunjungi tempat-tempat bersejarah yang dapat memberikan pengetahuan yang baru, iklim membaca juga dapat memberikan pengetahuan dan wawasan yang banyak sehingga mahasiswa yang satu mempunyai kemampuan kognitif yang terarah kepada kemampuankemampuan intelektual, kemampuan berpikir maupun kecerdasan yang akan dicapai melebihi mahasiswa lainnya. Kegiatan ekstrakurikuler dapat memberikan kemampuan psikomotorik yang terarah kepada keterampilanketerampilan yang dapat mendorong mahasiswa meningkatkan prestasi akademiknya. Kenyataan yang terjadi, modal budaya pada mahasiswa Fakultas Ekonomi dirasakan masih kurang, dilihat dari partisipasi mereka akan kegiatan-kegiatan yang berkaitan dengan seni dan budaya. 
Begitu pula pendidikan orang tua, anak yang mempunyai orang tua yang berpendidikan biasanya aspirasi dan harapan mereka akan prestasi anak-anak mereka sangat tinggi. Para orang tua akan memberikan dukungan langsung seperti membantu pekerjaan rumah, sehingga mereka mampu berprestasi lebih baik daripada anak yang memiliki orang tua yang tingkat pendidikannya rendah. Pada kenyataannya, masih ada orang tua dari mahasiswa Fakultas Ekonomi UNJ yang tingkat pendidikannya rendah. Namun bagaimanapun juga tingkat pendidikan orang tua yang rendah tidak semata-mata menyebabkan hambatan bagi mencapai kesuksesan prestasi akademik mereka.

Saat sekarang ini biaya pendidikan sangat tinggi, hal tersebut mengakibatkan masyarakat khususnya keluarga yang kurang mampu sangat kesulitan untuk meningkatkan mutu pendidikan anak-anaknya. Akibat kekurangmampuan keluarga dalam meningkatkan mutu pendidikan, maka tingkat kesejahteraan keluarga tersebut kurang baik. Dalam hal pendapatan orang tua, anak yang mempunyai orang tua yang berpendapatan tinggi biasanya akan memberikan dukungan dalam hal fasilitas dan dukungan dalam hal kesehariannya, sehingga mereka mampu berprestasi lebih baik daripada anak yang memiliki orang tua yang tingkat pendapatannya lebih rendah. Pada kenyataannya di lingkungan Fakultas Ekonomi UNJ rata-rata tingkat pendapatan orang tua dibandingkan dengan kebutuhan akan biaya pendidikan yang tinggi dirasakan masih rendah. Sama halnya dengan tingkat pendidikan, bagaimanapun juga tingkat pendapatan orang tua yang rendah tidak menjadi hal mendasar yang dapat menyebabkan rendahnya prestasi akademik mereka.

Prestasi akademik yang dicapai mahasiswa berbeda-beda, ada mahasiswa yang berprestasi tinggi, sedang, dan ada pula mahasiswa yang berprestasi rendah. Hal ini tentu saja dipengaruhi oleh berbagai macam faktor, baik faktor intern (berasal dari dalam mahasiswa itu sendiri) maupun faktor ekstern (berasal dari luar mahasiswa itu sendiri). Kebiasaan atau sesuatu yang dilakukan secara berulang-ulang merupakan suatu cara bertindak yang telah dikuasai, diuji, seragam, dan berlaku secara otomatis tanpa dipikirkan lagi, yang dapat mempengaruhi tujuan mahasiswa untuk mencapai hasil belajar yang di inginkan.

Prestasi akademik dapat dilihat pada tiap akhir perkuliahan. Ketika anak didik mendapatkan bahwa prestasi akademiknya kurang baik, 
maka dampak yang terjadi adalah anak didik tersebut akan berusaha mencapai prestasi akademik yang lebih baik. Faktor yang dapat mempengaruhi prestasi akademik timbul dari dalam dan luar diri mahasiswa adalah modal budaya, tingkat pendidikan orang tua dan tingkat pendapatan orang tua.

Dari penelitian-penelitian yang lain sebelumnya dapat dilihat bahwa hasil dan kesimpulan penelitian yang dilakukan dapat berbeda-beda, hal ini mungkin disebabkan karena karakteristik tiap negara yang diteliti berbeda-beda. Menyadari bahwa modal budaya, tingkat pendidikan orang tua dan tingkat pendapatan orang tua mempunyai pengaruh dalam pencapaian prestasi akademik mahasiswa, maka peneliti tertarik untuk meneliti faktor-faktor yang dapat mempengaruhi prestasi akademik pada mahasiswa Fakultas Ekonomi Universitas Negeri Jakarta.

\section{Pembatasan Masalah}

Masalah prestasi akademik mencakup aspek yang sangat luas dan kompleks sifatnya. Karena keterbatasan peneliti dalam upaya pemecahan masalah tersebut, maka peneliti membatasi masalah yang akan diteliti hanya pada masalah pengaruh modal budaya, tingkat pendidikan orang tua dan tingkat pendapatan orang tua terhadap prestasi akademik.

\section{KAJIAN TEORI \\ Prestasi Akademik}

Prestasi akademik adalah hasil pelajaran yang diperoleh dari kegiatan belajar di sekolah atau perguruan tinggi yang bersifat kognitif dan biasanya ditentukan melalui pengukuran dan penilaian. Keberhasilan prestasi akademik mahasiswa selama mengikuti pendidikan di perguruan tinggi dinilai dari penilaian mata kuliah, penilaian semester, penilaian akhir tahun akademik dan penilaian akhir program studi. Tolak ukur yang dipakai dalam prestasi akademik adalah Indeks Prestasi Kumulatif (IPK).

Menurut Sobur (2006) prestasi akademik merupakan perubahan dalam hal kecakapan tingkah laku, ataupun kemampuan yang dapat bertambah selama beberapa waktu dan tidak disebabkan proses pertumbuhan, tetapi adanya situasi belajar. Perwujudan bentuk proses hasil belajar tersebut dapat berupa pemecahan lisan maupun tulisan, dan keterampilan serta pemecahan masalah langsung dapat diukur atau dinilai dengan tes yang terstandar.

Sedangkan menurut J.P Chaplin yang dikutip oleh Thantawy R (2004), Educational or academic achievement 
is a specified level of attainment or proficiency in academic work as evaluated by teachers, by standardized tests, or by teachers tests, or by a combination of both.

Selanjutnya menurut Suryabrata (2006) prestasi akademik adalah hasil belajar terakhir yang dicapai oleh siswa dalam jangka waktu tertentu, yang mana di sekolah prestasi akademik siswa biasanya dinyatakan dalam bentuk angka atau simbol tertentu. Kemudian dengan angka atau simbol tersebut, orang lain atau siswa sendiri akan dapat mengetahui sejauhmana prestasi akademik yang telah dicapai. Dengan demikian, prestasi akademik di sekolah merupakan bentuk lain dari besarnya penguasaan bahan pelajaran yang telah dicapai siswa, dan rapor bisa dijadikan hasil belajar terakhir dari penguasaan pelajaran tersebut.

Berdasarkan uraian dari beberapa pendapat tersebut diatas, maka dapat dikatakan bahwa prestasi akademik merupakan hasil pencapaian ataupun kemampuan atau kecakapan yang menghasilkan perubahan dalam jangka waktu tertentu yang dapat diukur atau dinilai dari evaluasi pengajar, tes-tes yang sudah distandarisasi atau dari kombinasi keduanya serta dinyatakan dalam bentuk angka atau simbol tertentu.
Lain halnya prestasi akademik yang dikemukakan oleh Setiawan (2006), prestasi akademik adalah istilah untuk menunjukkan suatu pencapaian tingkat keberhasilan tentang suatu tujuan, karena suatu usaha belajar telah dilakukan oleh seseorang secara optimal. Didukung oleh Bloom dalam Azwar (2002) yang berpendapat bahwa prestasi akademik adalah mengungkap keberhasilan seseorang dalam belajar.

Sedangkan definisi prestasi akademik menurut Azwar (2002) adalah bukti peningkatan atau pencapaian yang diperoleh seorang siswa sebagai pernyataan ada tidaknya kemajuan atau keberhasilan dalam program pendidikan.

Ditambahkan oleh Djamarah (2002) mendefinisikan prestasi akademik adalah hasil yang diperoleh berupa kesan-kesan yang mengakibatkan perubahan dalam diri individu sebagai hasil akhir dari aktivitas belajar.

Berdasarkan uraian dari beberapa pendapat tersebut, maka dapat dikatakan bahwa prestasi akademik adalah hasil atau pencapaian keberhasilan yang diperoleh karena usaha belajar atau sebagai hasil akhir dari aktivitas belajar.

Menurut Azwar (2004) secara umum, ada dua faktor yang mempengaruhi prestasi akademik 
seseorang, yaitu faktor internal dan faktor eksternal. Faktor internal meliputi antara lain faktor fisik dan faktor psikologis.

Faktor fisik berhubungan dengan kondisi fisik umum seperti penglihatan dan pendengaran. Faktor psikologis menyangkut faktor-faktor non fisik, seperti minat, motivasi, bakat, intelegensi, sikap dan kesehatan mental. Faktor eksternal meliputi faktor fisik dan faktor sosial. Faktor fisik menyangkut kondisi tempat belajar, sarana dan perlengkapan belajar, materi pelajaran dan kondisi lingkungan belajar. Faktor sosial menyangkut dukungan sosial dan pengaruh budaya.

Menurut Ahmadi dan Supriyono (2004), faktor-faktor yang mempengaruhi prestasi akademik antara lain:

A. Faktor internal

1) Faktor jasmaniah (fisiologi), yang termasuk faktor ini misalnya penglihatan, pendengaran, struktur tubuh.

2) Faktor psikologis, terdiri atas:

a. Faktor intelektif yang meliputi (1) Faktor potensial yaitu kecerdasan dan bakat, (2) Faktor kecakapan nyata yaitu prestasi yang telah dimiliki.

b. Faktor non-intelektif, yaitu unsurunsur kepribadian tertentu seperti sikap, kebiasaan, minat, kebutuhan, motivasi, emosi, penyesuaian diri

c. Faktor kematangan fisik maupun psikis.

d. Faktor lingkungan spiritual atau keamanan.

B. Faktor eksternal

1) Faktor sosial yang terdiri atas Lingkungan keluarga, Lingkungan sekolah, Lingkungan masyarakat dan Lingkungan kelompok

2) Faktor budaya seperti adat istiadat, ilmu pengetahuan, teknologi, kesenian.

3) Faktor lingkungan fisik seperti fasilitas rumah, fasilitas belajar, iklim.

Berdasarkan pengertianpengertian tersebut diatas, maka dapat ditarik kesimpulan bahwa prestasi akademik adalah hasil pencapaian ataupun kemampuan atau kecakapan yang menghasilkan perubahan dalam jangka waktu tertentu karena usaha belajar, yang dapat diukur atau dinilai dari evaluasi pengajar, tes-tes yang sudah distandarisasi atau dari kombinasi keduanya serta dinyatakan dalam bentuk angka atau simbol tertentu.

\section{Modal Budaya}

Kata modal budaya memang tidak sering dibahas atau didengar orang awam, dan tidak banyak pula orang meneliti mengenai modal 
budaya dikaitkan dengan bidang pendidikan. Modal budaya menyangkut kegiatan partisipasi dalam kegiatan-kegiatan budaya. Adapun beberapa pengertian modal budaya dapat dilihat dalam pengertianpengertian modal budaya yang diungkapkan oleh beberapa ahli di bawah ini :

Lamount dan Lareau (1988) mengungkapkan:"At the most general level cultural capital pertains to knowledge of the dominant conceptual and normative codes inscribed in a culture. Cultural capital is used by individuals or groups positioned at different levels in social hierarchies as a means of either promoting relative social advantage or as a generalized currency which can be exchanged for other economic or social assets. Consequently, cultural capital enables individuals and families with knowledge of institutionalized high-status cultural signals (attitudes, preferences, formal knowledge, behaviors, goods and credentials) to exclude others from advantaged social positions or highstatus groups".

Begitu pula menurut Dimaggio dan Mohr yang dikutip oleh Lamont dan Lareau (1988): "Cultural capital has been operasionalized knowledged of high culture and educational attainment. Others defined it as the curriculum of elite school, the symbolic mastery of practices, the capacity to perform tasks in culturally acceptable ways, and participation in high culture events".

Menurut Bourdieu (1986) pada The Forms of Capital: Cultural capital is forms of knowledge, skills, education, and advantages that a person has, which give them a higher status in society. Parents provide their children with cultural capital by transmitting the attitudes and knowledge needed to succeed in the current educational system.

Stanton-Salazar \& Dornbusch (1995) meneliti bagaimana orang-orang dengan jenis yang diinginkan modal budaya (dan bahasa) di sekolah mentransformasikan modal ini menjadi hubungan instrumental atau modal sosial dengan agen kelembagaan yang dapat mengirimkan sumber daya yang berharga untuk orang tersebut, melanjutkan kesuksesan mereka di sekolah.

Menurut Jaeger (2010) mengenai modal budaya yaitu cultural capital is a scarce resource which equips individuals with knowledge, practical skills, and a sense of "the rules of the game" in the educational system which is recognized and rewarded by institutional gatekeepers and peers. 
Dumais (2002) mengemukakan bahwa "this cultural capital is embedded in children's knowledge, language, and mannerisms". Bourdieu dalam Dumais (2002) menyatakan bahwa : "academic success is directly dependent upon cultural capital and on the inclination to invest in the academic market".

Ditambahkan pula oleh De Graf dan Kraaykamp (2000) yang menyatakan bahwa children who have more cultural capital (having been exposed to it from birth in their upper middle-and upper-class families) feel more comfortable in school, communicate easily with teachers, and are therefore more likely to do well in school.

Dari beberapa penelitian yang dikemukakan di atas, dapat dilihat bahwa jika anak didik memiliki modal budaya yang lebih maka akan berdampak pada penigkatan prestasi akademik. Jadi dapat disimpulkan bahwa modal budaya dapat mempengaruhi prestasi akademik.

\section{Tipe-tipe Modal Budaya}

Menurut Bourdieu yang membedakan modal budaya ke dalam tiga jenis modal, yaitu:

1. Modal budaya berwujud, yaitu modal budaya yang diwujudkan baik secara sadar diperoleh secara pasif dari "mewarisi" sifat-sifat diri sendiri. Disini digunakan tidak dalam arti genetik tetapi dalam arti penerimaan dari waktu ke waktu, biasanya melalui sosialisasi, budaya dan tradisi dari keluarga.

2. Modal budaya objektifikasi, yaitu modal budaya yang dapat dilihat dari objek. Terdiri dari benda-benda fisik yang dimiliki, seperti instrumen ilmiah atau karya seni. Barang-barang budaya dapat menular baik untuk keuntungan ekonomi dan untuk tujuan simbolis.

3. Modal budaya yang dilembagakan, yaitu modal budaya yang terdiri dari pengakuan kelembagaan, paling sering dalam bentuk kualifikasi dari modal budaya yang dimiliki oleh seorang individu.

Berdasarkan pengertianpengertian tersebut diatas, maka dapat ditarik kesimpulan bahwa modal budaya adalah bentuk pemahaman tentang kode konseptual dan normatif yang dominan tertulis dalam suatu budaya yang meliputi pengetahuan, keahlian dan keluarga.

\section{Tingkat Pendidikan Orang Tua}

Pendidikan sangatlah penting peranannya dalam kehidupan bermasyarakat. Dengan memiliki pendidikan yang cukup maka seseorang akan mengetahui mana yang baik dan mana yang dapat 
menjadikan seseorang menjadi berguna baik untuk dirinya sendiri maupun untuk orang lain yang membutuhkannya. Adapun pengertian pendidikan yang lebih jelas, dapat dilihat dalam pengertian-pengertian pendidikan yang diungkapkan oleh beberapa pakar pendidikan di bawah ini:

Ahmad D. Marimba dalam Hasbullah (2008) mengutarakan bahwa pendidikan adalah bimbingan atau pimpinan secara sadar oleh pendidik terhadap perkembangan jasmani dan rohani terdidik menuju terbentuknya kepribadian yang utama.

Ngalim Purwanto (2007) menyatakan bahwa pendidikan ialah segala usaha orang dewasa dalam pergaulannya dengan anak-anak untuk memimpin perkembangan jasmani dan rohani ke arah kedewasaan.

Pengertian pendidikan diatas menjelaskan bahwa segala usaha orang dewasa dalam pergaulannya yang dilakukan secara terus menerus dan spontan untuk perkembangan jasmani dan rohani ke arah kedewasaannya.

John Dewey dalam Kartini Kartono (2001) mengatakan bahwa : For it assumed that the aim of education is to enable individuals to continue their education or that object and reward of learning is continued capacity for growth. And it is well to remind ourselves that education as such has no aims. Only persons, parents, teachers, etc. have aims, not an abstract idea like education. And consequently their purpose are indefinitely varied, differing with different changing, as children grow and with the growth of experience on the part of the who teaches.

Berdasarkan pendapat para ahli diatas, dapat ditarik kesimpulan bahwa pendidikan merupakan perkembangan semua potensi manusia untuk menyiapkan peserta didik melalui kegiatan bimbingan, pengajaran atau latihan menuju terbentuknya kepribadian yang utama, sehingga dapat mencapai cita-citanya.

Menurut Sudirman dalam Hasbullah (2008), pendidikan diartikan sebagai usaha yang dijalankan oleh seseorang atau kelompok orang lain agar menjadi dewasa atau mencapai tingkat hidup atau penghidupan yang lebih tinggi dalam arti mental.

Fuad Ihsan

(2003) menyebutkan bahwa "pendidikan adalah proses dimana seseorang mengembangkan kemampuan sikap dan bentuk tingkah laku lainnya didalam masyarakat dimana ia hidup, proses sosial dimana orang dihadapkan pada pengaruh lingkungan yang terpilih dan terkontrol (khususnya yang datang 
dari sekolah), sehingga dia dapat memperoleh atau mengalami perkembangan kemampuan sosial dan kemampuan individu yang optimum".

Menurut GBHN tahun 1973 dalam Ihsan (2003) disebutkan bahwa "pendidikan pada hakikatnya adalah usaha sadar untuk mengembangkan kepribadian dan kemampuan di dalam dan di luar sekolah dan berlangsung seumur hidup".

Pendapat yang sama
dikemukakan oleh Nadir Celikoz (2010), "education is a process of changing and improving behaviour at all levels of life".

Menurut Ali Saifullah (2003), education is the process by which the individual is taught loyalty and conformity by which the human mind is disciplined and developed. Dari berbagai pendapat para ahli diatas maka dapat dikatakan bahwa pendidikan adalah proses mengembangkan sikap dan tingkah laku. Perkembangan tersebut membutuhkan proses yang panjang dan lama karena untuk membentuk tingkah laku yang baik harus ada niat dari dalam diri individu tersebut.

Menurut Undang-undang

Republik Indonesia No. 20 tahun 2003 tentang sistem Pendidikan Nasional Pasal 1 ayat 1 yaitu "pendidikan adalah usaha sadar dan terencana untuk mewujudkan suasana belajar dan proses pembelajaran agar peserta didik secara aktif mengembangkan potensi dirinya untuk memiliki kekuatan spiritual keagamaan, pengendalian diri, kepribadian, kecerdasan, akhlak mulia, serta ketrampilan yang diperlukan dirinya, masyarakat bangsa dan negara".

Ali Saifullah menambahkan pengertian pendidikan yaitu usaha manusia untuk membina kepribadiannya sesuai dengan nilainilai di dalam masyarakat dan kebutuhannya.

$$
\text { Lester D. Crow (2004) }
$$

berpendapat, pendidikan adalah proses individualisasi dan sosialisasi yang lebih lanjut dapat dinyatakan bahwa kemajuan yang diperoleh seseorang berarti juga kemajuan bagi masyarakat dimana ia bertempat tinggal.

Dari berbagai pendapat para ahli diatas maka dapat dikatakan bahwa pendidikan merupakan sebuah proses untuk mengembangkan pikiran, watak, keterampilan yang diperoleh melalui pembelajaran dalam rangka mencapai tujuan.

Berdasarkan pengertianpengertian tersebut diatas, maka dapat ditarik kesimpulan bahwa pendidikan adalah upaya untuk mengarah pada tercapainya perkembangan yang dapat merangsang suatu cara berpikir yang 
rasional, kreatif dan sistematis. Dengan pendidikan dapat memperluas keilmuan, meningkatkan kemampuan dan potensi serta membuat seseorang lebih peka terhadap setiap gejala-gejala sosial yang muncul.

Sistem pendidikan formal memiliki tingkat atau jenjang mulai dari Sekolah Dasar sampai pada Tingkat Perguruan Tinggi, termasuk berbagai program atau lembaga khusus untuk latihan teknik atau profesi dengan waktu sepenuhnya.

Menurut Yustina Rostiawati (1992), tingkat pendidikan adalah jenjang, taraf secara kronologi yang ada pada pendidikan formal atau pendidikan di sekolah.

Diperjelas oleh Yatriman dalam Supramono (2005), tingkat pendidikan adalah jenjang dalam proses belajar yang dicapai seseorang secara sadar yang berlangsung secara formal.

Berdasarkan definisi diatas, ditegaskan bahwa tingkat pendidikan adalah jenjang yang mengatur sistem penyampaian pendidikan formal atau pendidikan sekolah yang mana ditetapkan berdasarkan pada tingkat perkembangan para peserta didik serta keluasan dan kedalaman bahan pengajaran .

Menurut yang diungkapkan oleh Ace Suryadi (1999) bahwa jenjang pendidikan adalah persekolahan yang berkesinambungan antara satu jenjang dengan jenjang lainnya, jenjang pendidikan yang termasuk jalur pendidikan sekolah terdiri atas pendidikan dasar, pendidikan menengah, pendidikan tinggi.

Sedangkan menurut Umar Tirtarahardja (2005), jenjang pendidikan adalah suatu tahap dalam pendidikan berkelanjutan yang ditetapkan berdasarkan tingkat perkembangan peserta didik serta keluasan ke dalam bahan pengajaran. Jalur pendidikan sekolah dilaksanakan secara bertingkat yang terdiri atas tingkat pendidikan dasar, pendidikan menengah, dan tingkat pendidikan tinggi.

Didukung oleh Himpunan Peraturan Perundang-undangan Bidang Kependidikan yang dikutip oleh Philip Joe Molle (2000), pasal 12 ayat 1 menyatakan jenjang pendidikan yang termasuk jalur pendidikan sekolah terdiri dari atas pendidikan dasar, pendidikan menengah, dan pendidikan tinggi.

Dari beberapa pengertian jenjang pendidikan diatas, maka dapat diketahui bahwa jenjang pendidikan merupakan suatu tahapan pendidikan yang berkesinambungan antara tingkat perkembangan peserta didik, tujuan pendidikan yang akan dicapai, dan 
kemampuan peserta didik yang akan dikembangkan.

\section{Menurut Sumardiono (2007)} tentang definisi "jenjang pendidikan adalah tahapan pendidikan yang ditetapkan berdasarkan tingkat perkembangan peserta didik, tujuan yang akan dicapai, dan kemampuan yang dikembangkan".

Sedangkan M. Alisuf Sabri (1999) mengatakan bahwa jenjang pendidikan adalah tahap pendidikan berkelanjutan yang ditetapkan berdasarkan tingkat perkembangan peserta didik, tingkat kerumitan bahan pengajaran dan cara penyajian bahan pengajaran.

Pendapat yang sama juga dikemukakan oleh Retnaningsih Burham (2008) jenjang pendidikan adalah tahap pendidikan berkelanjutan yang ditetapkan berdasarkan tingkat perkembangan peserta didik, tingkat kerumitan bahan pengajaran dan cara penyajian bahan pengajaran.

Sementara menurut Benny Susetyo (2005) menyatakan jenjang pendidikan adalah tahapan pendidikan yang ditetapkan berdasarkan tingkat perkembangan peserta didik, tujuan yang akan dicapai, dan kemampuan yang dikembangkan.

Menurut Soetjipto dan Raflis Kosasi (2004) menyebutkan bahwa jenjang pendidikan adalah unsur atau komponen sistem pendidikan nasional, yaitu termasuk dalam komponen organisasi. Jenjang pendidikan terdiri dari atas pendidikan dasar, pendidikan menengah, dan pendidikan tinggi.

Dalam Undang-undang tentang sistem pendidikan nasional pasal 1 ayat 5 yang dikutip oleh Hasbullah (2008), tingkat pendidikan adalah tahap pendidikan berkelanjutan yang ditetapkan berdasarkan tingkat perkembangan para peserta didik serta keluasan dan kedalaman bahan pengajaran.

Sedangkan menurut Fuad Ihsan (2003) dalam bukunya Dasar-dasar Kependidikan menyatakan "jenjang pendidikan adalah tahap pendidikan yang berkelanjutan yang ditetapkan berdasarkan tingkat perkembangan peserta didik, tingkat kerumitan bahan pengajaran dan cara menyajikan bahan pengajaran. Jenjang pendidikan sekolah terdiri dari pendidikan dasar, pendidikan menengah dan pendidikan tinggi".

Berdasarkan UU No. 20 tahun 2004, tingkat pendidikan formal terdiri atas pendidikan dasar, pendidikan menengah, dan pendidikan tinggi.

1. Pendidikan dasar, terdiri dari:

a. Sekolah dasar / Madrasah Ibtidaiyah

b. Sekolah Menengah Pertama / Madrasah Tsarawiyah 
2. Pendidikan menengah, terdiri dari:
a. Sekolah Menengah Atas dan Madrasah Aliyah
b. Sekolah Kejuruan dan Madrasah Aliyah Kejuruan

3. Pendidikan tinggi, terdiri dari:
a. Akademi
b. Institut
c. Sekolah Tinggi
d. Universitas

Menurut Zahara Idris (2001) juga mengemukakan bahwa pendidikan formal terdiri dari pendidikan dasar, menengah dan tinggi.

- Pendidikan dasar : SD dan SMP

- Pendidikan menengah : SMA dan SMK

- Pendidikan tinggi : diploma, sarjana, magister, doktor dan spesialis.

Menurut Soedijarto, tingkat pendidikan:

- Pendidikan dasar seperti SD dan SMP

- Pendidikan menengah seperti SMA dan SMK

- Pendidikan tinggi seperti diploma, sarjana dan magister.

Berdasarkan seluruh pendapat para ahli mengenai tingkat pendidikan di atas maka dapat disimpulkan bahwa tingkat pendidikan adalah tahapan pendidikan berkelanjutan yang berdasarkan pada tingkat perkembangan peserta didik serta ke dalaman bahan pengajaran dimulai dari pendidikan dasar, pendidikan menengah, dan pendidikan tinggi.

Menurut Ngalim Purwanto (2007), orang tua adalah pendidik sejati, pendidik karena kodratnya. Karena memang sudah secara kodrat orang tua mendidik anak, maka yang diharapkan pasti yang terbaik untuk anaknya. Abu Ahmadi (2007) menyatakan bahwa tingkat pendidikan orang tua adalah pendidikan formal tertinggi yang berhasil ditempuh oleh orang tua.

Menurut Dalyono (2005), faktor orang tua sangat besar pengaruhnya terhadap keberhasilan anak dalam belajar. Tinggi rendahnya pendidikan orang tua, besar kecilnya penghasilan, cukup atau kurang perhatian dan bimbingan orang tua, rukun atau tidaknya kedua orang tua, akrab atau tidaknya hubungan orang tua dengan anak-anak, tenang atau tidaknya situasi dalam rumah, semuanya mempengaruhi keberhasilan belajar.

Dari teori yang dikemukakan di atas dapat disimpulkan, tingkat pendidikan orang tua dapat berkorelasi dengan prestasi akademik. Pernyataan tersebut juga didukung oleh hasil penelitian yang dilakukan oleh Jerrim dan Micklewright (2009) yang menyatakan ada korelasi yang kuat antara tingkat pendidikan ibu dan ayah 
atau orang tua dalam suatu keluarga dengan prestasi akademik anak. Orang tua memegang peranan yang sangat penting dalam prestasi akademik anak. Menurut Jerrim dan Micklewright (2009): This correlation could be identified as an associate with the child's cognitive ability. Children who have mothers or fathers with good educational qualifications tend to have academic value better than children whose parents are less educated, although both families are from low SES. Jerrim \& Micklewright (2009) menegaskan bahwa tidak mudah untuk melakukan generalisasi sejauh mana pentingnya pendidikan orang tua untuk kemampuan kognitif siswa.

Pendidikan orang tua memberikan stimulus yang baik terhadap dukungan akademik dimana orang tua menginginkan anaknya menempuh pendidikan yang sama atau bahkan melebihi mereka. Lee dan Burkham (2002) dalam Taylor\& Yu (2008) menyatakan bahwa : variations in cognitive abilities of children when starting school is also associated with educational background of parents. Educated parents can provide direct support such as help on their homework than parents whose level of education below the stage. Perceptions of good academic achievement is both of parents are educated.
Menurut Joan dan Claire (2010) mengemukakan bahwa : parents' level of education have been regarded as predictors of children's academic achievement. Yang dapat diartikan bahwa tingkat pendidikan orang tua dianggap sebagai prediktor prestasi akademik anak-anak.

Jadi dapat disimpulkan bahwa tingkat pendidikan orang tua adalah pendidikan formal tertinggi yang berhasil ditempuh oleh orang tua.

\section{Tingkat Pendapatan Orang Tua}

Pendapatan

akan mempengaruhi status sosial seseorang, terutama akan ditemui dalam masyarakat yang materialis dan tradisional yang menghargai status sosial ekonomi yang tinggi terhadap kekayaan.

Menurut Sundoyo Pitono (1982) mendefinisikan pendapatan adalah sebagai berikut: Seluruh penerimaan baik berupa uang ataupun barang baik dari pihak lain maupun dari hasil sendiri, dengan jalan dinilai sejumlah atas harga yang berlaku saat ini.

The Liang Gie memberikan pengertian income atau pendapatan atau penghasilan adalah seluruh pendapatan seseorang baik berupa uang maupun barang yang diperolehnya untuk suatu jangka waktu tertentu. Sedangkan menurut Winardi 
(1977) mendefinisikan income atau pendapatan atau penghasilan adalah berupa uang atau hasil materiil-materiil lainnya yang dicapai daripada penggunaan kekayaan atau jasa manusia bebas (perusahaan atau individu) dalam produksi.

Menurut Standar Akuntansi Keuangan No.23, pendapatan sebagai salah satu elemen penentuan laba rugi suatu perusahaan belum mempunyai pengertian yang seragam. Hal ini disebabkan pendapatan biasanya dibahas dalam hubungannya dengan pengukuran dan waktu pengakuan pendapatan itu sendiri. Secara garis besar, konsep pendapatan dapat ditinjau dua segi, yaitu menurut ilmu ekonomi dan menurut ilmu akuntansi.

Pendapatan menurut ilmu ekonomi merupakan nilai maksimum yang dapat dikonsumsi oleh seseorang dalam suatu periode dengan mengharapkan keadaan yang sama pada akhir periode seperti keadaan semula. Pengertian tersebut menitikberatkan pada total kuantitatif pengeluaran terhadap konsumsi selama satu periode. Dengan kata lain, pendapatan adalah jumlah harta kekayaan awal periode ditambah keseluruhan hasil yang diperoleh selama satu periode, bukan hanya yang dikonsumsi.
Definisi pendapatan menurut ilmu ekonomi menutup kemungkinan perubahan lebih dari total harta kekayaan badan usaha pada awal periode, dan menekankan pada jumlah nilai statis pada akhir periode. Secara garis besar pendapatan adalah jumlah harta kekayaan awal periode ditambah perubahan penilaian yang bukan diakibatkan perubahan modal dan hutang.

Banyak konsep pendapatan didifinisikan dari berbagai literatur akuntansi dan teori akuntansi. Namun pada dasarnya konsep pendapatan dapat ditelusuri dari dua sudut pandang, yaitu :

a. Pandangan yang menekankan pada pertumbuhan atau peningkatan jumlah aktiva yang timbul sebagai hasil dari kegiatan operasional perusahaan. Pendekatan yang memusatkan perhatian kepada arus masuk atau inflow adalah revenue is an inflow of assets in the form of cash, receivables of other property for customer or client, which results from sales of merchandises or rendering of services, or from investment for instance, interest may be carned on bonds or saving deposit. Pandangan yang menekankan kepada penciptaan barang dan jasa oleh perusahaan serta penyerahan barang dan jasa atau outflow. 


Vernon Kam (1990)
menyatakan revenue is the gross
increase in the value of asset and
capital and that the increase eventually
pertain to cash. For the primary
operations of the business, the cash
inflow is created mainly by the
production and sale of the output of the firm.

Ditambahkan pula oleh Kam bahwa konsep dasar pendapatan pada dasarnya adalah suatu proses mengenai arus penciptaan barang dan jasa oleh perusahaan selama jangka waktu tertentu. The basic concept of revenue is that it is a flow process the creation of goods and services by an enterprises during specific internal of time.

Biro Pusat Statistik merinci
pendapatan dalam kategori sebagai
berikut:

1) Pendapatan berupa uang adalah segala penghasilan berupa uang yang sifatnya regular dan diterima biasanya sebagai balas atau kontra prestasi, sumbernya berasal dari :

a. Gaji dan upah yang diterima dari gaji pokok, kerja sampingan, kerja lembur dan kerja kadang-kadang

b. Usaha sendiri yang meliputi hasil bersih dari usaha sendiri, komisi, penjualan dari kerajinan rumah.

c. Hasil investasi yakni pendapatan yang diperoleh dari hak milik tanah.
Keuntungan serial yakni pendapatan yang diperoleh dari hak milik.

2) Pendapatan yang berupa barang yaitu : Pembayaran upah dan gaji yang ditentukan dalam beras, pengobatan, transportasi, perumahan dan rekreasi.

Pada dasarnya yang berkenaan dengan pendapatan orang tua atau pendapatan keluarga menurut Soediyono (1990) terdiri dari:

a. Upah dan gaji, merupakan pendapatan yang diperoleh rumah tangga keluarga sebagai imbalan terhadap penggunaan jasa sumber tenaga kerja yang mereka gunakan dalam pembentukan produk nasional.

b. Sewa, meliputi semua macam sewa atas pemakaian aktiva tetap oleh pihak lain atau oleh pemiliknya sendiri.

c. Bunga, meliputi semua pembayaran modal pinjaman yang dibayar oleh sektor, baik sektor keluarga maupun sektor perusahaan.

d. Laba, merupakan perbedaan antara jumlah penerimaan penjualan perusahaan dengan jumlah biaya yang dikeluarkan oleh perusahaan.

Jadi pendapatan yang diterima seseorang dalam hal ini orang tua sebagai kontraprestasi atau imbalan atas kegiatan dalam ekonomi dengan menggunakan faktor-faktor produksi 
dapat berbentuk antara lain: gaji, bunga/deviden, upah/honor, komisi, jasa transportasi, laba/keuntungan, hasil sewa, hasil panen, dan lain-lain.

Tingkat pendapatan antara orang tua satu dengan lainnya tidak sama, biasanya hal ini tergantung dari jenis pekerjaan, lamanya pekerjaan, pangkat atau jabatan yang diduduki dan sebagainya.

Hasil penelitian yang dilakukan oleh Pamela E-Davis-Kean (2005): This study examined the process of how socioeconomic status, specifically parents' education and income, indirectly relates to children's academic achievement through parents' beliefs and behavioursBerdasarkan pengertian-pengertian tersebut diatas, pendapatan bisa berupa barang atau uang, bisa berupa gaji, upah, pembagian keuntungan, pendapatan diperoleh dalam suatu jangka waktu tertentu. Jadi dapat disimpulkan bahwa tingkat pendapatan orang tua adalah sejumlah hasil yang diperoleh orang tua dalam jangka waktu satu bulan dalam bentuk uang yang berasal dari gaji dan bukan gaji.

\section{METODE PENELITIAN}

Persamaan yang digunakan dalam penelitian ini adalah:

$$
\begin{aligned}
& P A_{i}=\alpha+\beta_{1} M B_{i}+\beta_{2} T P O_{i}+\beta_{3} T P d O \\
& +\varepsilon_{i}
\end{aligned}
$$

Dimana variabel yang digunakan adalah prestasi akademik (PA) dipengaruhi oleh modal budaya $(\mathrm{MB})$, tingkat pendidikan orang tua (TPO) dan tingkat pendapatan orang tua (TPdO). Dari hasil estimasi di atas, maka diharapkan penelitian ini dapat menjawab permasalahan dan tujuan yang diharapkan.

Populasi dalam penelitian ini adalah seluruh mahasiswa Fakultas Ekonomi, populasi terjangkaunya adalah mahasiswa Jurusan Ekonomi dan Administrasi angkatan 2009. Jenis data yang digunakan adalah data primer dan data sekunder yang bersumber dari mahasiswa dan Fakultas Ekonomi UNJ.

Penelitian dilakukan dengan menggunakan metode survei. Penelitian menggunakan instrumen yang berbentuk kuesioner untuk variabel modal budaya dan data sekunder dari kampus untuk mengukur masing-masing variabel lain yaitu prestasi akademik, tingkat pendidikan orang tua dan tingkat pendapatan orang tua. Data untuk modal budaya terdiri dari beberapa indikator yang akan dikembangkan menjadi butir-butir pertanyaan. Sedangkan variabel lainnya berupa data sekunder.

Prestasi

akademik menggunakan data ordinal. Menurut Duwi Priyatno (2010), data ordinal 
adalah data hasil kategorisasi yang sifatnya tidak setara dan tidak dapat dilakukan perhitungan aritmatika. Angka yang diberikan menunjukkan peringkat dan tingkatan tertentu.

Tabel Kategori Prestasi Akademik (IPK)

\begin{tabular}{|c|c|c|}
\hline IPK & Kategori & Bobot \\
\hline $2,00-2,75$ & Memuaskan & 1 \\
\hline $2,76-3,50$ & $\begin{array}{c}\text { Sangat } \\
\text { Memuaskan }\end{array}$ & 2 \\
\hline $3,51-4,00$ & Istimewa & 3 \\
\hline
\end{tabular}

Sumber : Buku Pedoman Akademik

Modal budaya menggunakan kuesioner yang berdasarkan indikator dari variabel modal budaya dijabarkan dalam 34 butir pernyataan.

Tabel Kriteria Skor Tanggapan Responden

\begin{tabular}{|c|c|c|}
\hline $\begin{array}{c}\text { Skor } \\
\text { Responden }\end{array}$ & Kategori & Bobot \\
\hline $89-116$ & Sedang & 1 \\
\hline $117-143$ & Tinggi & 2 \\
\hline $144-170$ & Tinggi Sekali & 3 \\
\hline
\end{tabular}

Sumber : Data diolah

Tingkat pendidikan orang tua dilihat dari data sekunder melalui data bersumber oleh perguruan tinggi yang dilihat sistem informasi yang digunakan pada kampus yaitu SIAKAD UNJ mengenai data pendidikan terakhir orang tua. Tingkat pendidikan orang tua menggunakan data ordinal.

Tabel Kategori Tingkat Pendidikan Orang Tua

\begin{tabular}{|c|c|c|}
\hline $\begin{array}{c}\text { Tingkat } \\
\text { Pendidikan } \\
\text { Orang Tua }\end{array}$ & Kategori & Bobot \\
\hline
\end{tabular}

\begin{tabular}{|c|c|c|}
\hline SD dan SMP & Dasar & 1 \\
\hline $\begin{array}{c}\text { SMA, SMK dan } \\
\text { Sejenisnya }\end{array}$ & Menengah & 2 \\
\hline Diploma, & & 3 \\
Sarjana, & Tinggi & \\
Magister dan & & \\
Spesialis & & \\
\hline
\end{tabular}

Sumber : Zahara Idris (2001)

Tingkat pendapatan orang tua dilihat dari data sekunder melalui data bersumber oleh perguruan tinggi yang dilihat sistem informasi yang digunakan pada kampus yaitu SIAKAD UNJ mengenai data pendapatan orang tua. Dimana data pendapatan yang didapat dari tiap responden untuk data pendapatan orang tua terendah sebesar Rp. 800.000,- dan pendapatan orang tua tertinggi sebesar $\mathrm{Rp}$. 8.000.000,-. Yang kemudian data tersebut dirubah menjadi data ordinal. 
Tabel Kategori Tingkat

Pendapatan Orang Tua

\begin{tabular}{|c|c|c|}
\hline $\begin{array}{c}\text { Tingkat } \\
\text { Pendapatan } \\
\text { Orang Tua }\end{array}$ & Kategori & Bobot \\
\hline $\begin{array}{c}\text { Rp. } 800.000- \\
\text { Rp. 3.533.000 }\end{array}$ & Rendah & 1 \\
\hline $\begin{array}{c}\text { Rp. 3.533.001- } \\
\text { Rp. 7.266.000 }\end{array}$ & Sedang & 2 \\
\hline $\begin{array}{l}\text { Rp. 7.266.001- } \\
\text { Rp. } 10.999 .000\end{array}$ & Tinggi & 3 \\
\hline
\end{tabular}

Sumber : Data diolah

\section{Analisis Deskriptif}

Analisis deskriptif yang

dilakukan adalah dengan membuat tabulasi silang antara variabel dependen dengan variabel-variabel independen. Sehingga kita bisa melihat gambaran hubungan secara umum antara variabel dependen dan variabelvariabel independen yang dimasukkan ke dalam model. Dari tabulasi silang akan terlihat persentase prestasi akademik untuk tiap-tiap kategori yang terdapat dalam variabel, sehingga akan terlihat di kategori manakah persentase prestasi akademik yang paling besar terjadi di tempat penelitian.

\section{Persamaan Regresi Logistik}

Peneliti menggunakan prosedur regresi logistik yang lebih spesifik yaitu regresi logistik ordinal. Menurut Stanislaus (2009), regresi logistik ordinal adalah regresi logistik di mana variabel dependennya berupa variabel dengan skala ordinal. Angka yang dihasilkan mewakilkan suatu kategori tertentu yang dihasilkan dari penghitungan probabilitas terjadinya kategori tersebut. Bentuk dasar probabilitas dalam model logit dapat dijelaskan pada tabel berikut.

Persamaan odds ratio untuk variabel independen $X_{i}$ adalah: $p / 1-p=$ $\exp \left(b_{i}\right)$, disebut dengan rasio kecenderungan karena menunjukkan kecenderungan terjadinya kategori dengan nilai 1 bagi tiap variabel independen i. Apabila kita sudah mendapatkan model regresi logistik, maka rasio kecenderungan antar dua individu atau dua kelompok individu dapat dihitung dengan memanfaatkan nilai koefisien regresinya (slope). Nilai koefisien regresi positif akan menghasilkan dugaan odds ratio yang lebih dari 1, sebaliknya jika nilai koefisien negatif akan menghasilkan odds ratio yang kurang dari 1 .

\section{Uji Signifikansi Parsial}

Uji ini ingin melihat secara individual apakah suatu variabel independen berpengaruh signifikan terhadap variabel dependen. Uji signifikansi parsial pada regresi logistik menggunakan uji Wald. Menurut Stanislaus (2009), uji wald digunakan untuk menguji apakah masing-masing koefisien regresi logistik signifikan. Uji 
wald sama dengan kuadrat dari rasio koefisien regresi logistik B dan standard error S.E.

Rumus uji Wald $=(\text { B / S.E. })^{2}$.

Persyaratan : jika nilai P-value dari masing-masing koefisien dari variabel independen dan konstanta $\leq \alpha=0,05$, maka koefisien regresi untuk masingmasing variabel dependen dan konstanta signifikan.

\section{Uji Koefisien Nagelkerke $R$ Square}

Koefisien Nagelkerke R Square merupakan modifikasi dari koefisien Cox\&Snell $R$ Square agar nilai maksimumnya bisa mencapai satu dan mempunyai kisaran nilai antara 0 dan 1, sama seperti koefisien determinasi $R^{2}$ pada regresi linier berganda.

\section{HASIL DAN PEMBAHASAN Interpretasi Model}

Berdasarkan hasil pengolahan data, didapat $\operatorname{Ln}(p 1)=21,160+1,067$ $M B+1,040 \mathrm{TPO}+1,106 \mathrm{TPdO}$, yang menunjukkan bahwa terdapat pengaruh modal budaya, tingkat pendidikan orang tua dan tingkat pendapatan orang tua terhadap prestasi akademik pada mahasiswa Fakultas Ekonomi Universitas Negeri Jakarta.

Perhitungan persamaan regresi logistik ordinal menghasilkan koefisien variabel modal budaya $\left(\beta_{1}=1,106\right)$. Artinya, apabila variabel tingkat pendidikan orang tua (X2) dan tingkat pendapatan orang tua (X3) dianggap konstan maka akan meningkatkan prestasi akademik sebesar 1,106 pada konstanta 21,160. Begitu pula dengan koefisien variabel tingkat pendidikan orang tua $\left(\beta_{2}=1,040\right)$. Artinya, apabila variabel modal budaya (X1) dan tingkat pendapatan orang tua (X3) dianggap konstan maka akan meningkatkan prestasi akademik sebesar 1,040 pada konstanta 21,160 . Sama halnya dengan koefisien variabel tingkat pendapatan orang tua $\left(\beta_{3}=1,067\right)$. Artinya, apabila variabel modal budaya (X1) dan tingkat pendidikan orang tua (X2) dianggap konstan maka akan meningkatkan prestasi akademik sebesar 1,067 pada konstanta 21,160.

Perhitungan Odds Ratio pada variabel modal budaya $\left(\operatorname{Exp}\left(\beta_{1}\right)=\operatorname{Exp}\right.$ $(1,106)=3,022)$. Artinya, apabila variabel tingkat pendidikan orang tua (X2) dan tingkat pendapatan orang tua (X3) dianggap konstan maka modal budaya yang berpengaruh akan mempengaruhi prestasi akademik responden 3,022 kali lebih besar dibandingkan modal budaya yang tidak berpengaruh. Pada variabel tingkat pendidikan orang tua $\left(\operatorname{Exp}\left(\beta_{2}\right)=\operatorname{Exp}\right.$ $(1,040)=2,829)$. Artinya, apabila variabel modal budaya (X1) dan tingkat pendapatan orang tua (X3) dianggap 
konstan maka tingkat pendidikan orang tua yang berpengaruh akan mempengaruhi prestasi akademik responden 2,829 kali lebih besar dibandingkan tingkat pendidikan orang tua yang tidak berpengaruh. Pada variabel tingkat pendapatan orang tua $\left(\operatorname{Exp}\left(\beta_{3}\right)=\operatorname{Exp}(1,067)=2,907\right)$. Artinya, apabila variabel modal budaya (X1) dan tingkat pendidikan orang tua (X2) dianggap konstan maka tingkat pendapatan orang tua yang berpengaruh akan mempengaruhi prestasi akademik responden 2,907 kali lebih besar dibandingkan tingkat pendapatan orang tua yang tidak berpengaruh.

Dalam penelitian ini nilai koefisien Nagelkerke R Square sebesar 0,150 yang berarti variabel-variabel modal budaya, tingkat pendidikan orang tua dan tingkat pendapatan orang tua mampu menjelaskan variasi prestasi akademik mahasiswa sebesar $15 \%$ sedangkan sisanya dijelaskan oleh variabel-variabel lain diluar model.

\section{KESIMPULAN}

Kesimpulan

Variabel modal budaya berkontribusi paling besar dalam mempengaruhi prestasi akademik pada mahasiswa Fakultas Ekonomi Universitas Negeri Jakarta dilihat dari koefisiennya yang paling besar dibandingkan variabel lain yaitu sebesar 1,106. Hal ini bisa saja terjadi karena keahlian yang diturunkan orang tua terhadap anaknya dapat digunakan atau diterapkan sepenuhnya oleh anak pada saat sekarang karena sesuai dengan bidang keahlian yang sedang diambil oleh anak. Begitu pula ada kegiatan study tour atau studi banding yang dilakukan pada kegiatan belajar mengajar misalnya ke tempat-tempat bersejarah yang dikunjungi atau tempat wisata tampaknya cukup kuat membentuk pola modal budaya anak dalam bidang yang berkaitan, dalam hal ini bidang ekonomi.

\section{DAFTAR PUSTAKA}

Ahmadi, A., \& Supriyono, W., 2004. Psikologi belajar. Jakarta: PT Rineka Cipta.

Azwar, S., 2002. Tes Prestasi: Fungsi Pengembangan Pengukuran Prestasi Belajar. Yogyakarta: Pustaka Pelajar.

Burham, Retnaningsih. 2008. Peningkatan Pembelajaran dalam Sistem Pendidikan Nasional Indonesia: Tinjauan Pendidikan Sekolah dan Luar Sekolah. Jakarta: UNJ Press.

Celikoz, Nadir. 2010. Basic Factors That Affect General Academic 
Motivation levels of Candidate

Preschool Teacher, Journal

Education, Vol. 131 No. 1, p.113.

Dumais, Susan A, 2002. Cultural Capital, Gender, and School Success: The Role of Habitus.

Sociology of Education Vol.75:44-68.

Dills, Angela, 2006. Trends in the Relationship between

Socioeconomic Status and Academic Achievement. John E. Walker Department of Economics, Clemson University.

Djamarah, S.B., 2002. Psikologi belajar. Jakarta: PT Rineka Cipta.

Hasbullah. 2008. Dasar-dasar Ilmu

Pendidikan. Jakarta: Raja

Grafindo Persada.

Hopkins, Kenneth D. and Stanley, Julian C., 2000. Educational dan Psychological Measurement and Evaluation. New Jersey: Prentice Hall Inc.

Idris, Zahara. 2001. Dasar-dasar

Kependidikan. Jakarta : Angkasa

Raya.

Insan, Fuad. 2005. Dasar-dasar Kependidikan. Jakarta : PT. Rineka Cipta.

Jerrim, J \& Micklewright, J, 2009.

Children's Education and Parents' Socio-economic Status : Distinguishing $\mathrm{Te}$ Impact of Mothers and Fathers. University of Southampton \& Institute of education, University of London. London.

Joe Molle, Phillip. 2000. Himpunan Perundang-undangan Bidang Kependidikan. Jakarta: Novindo Pustaka Mandiri.

Kam, Vernon. 1990. Accounting Theory, 2nd edition. California State University.

Kartono, Kartini. 2001. Quo Vadis. Jakarta : Mandar Maju. p.26.

Lamont, Michele and Annette Lareau. 1988. Cultural Capital: Allusions, Gaps and Glissandos in Recent Theoretical Developments. Sociological Theory 6:153-168.

Lester D. Crow, 2004. Psikologi Pendidikan. Surabaya : PT. Bina IImu. p.12

Mads Meier Jæger, 2010. Does Cultural Capital Really Affect Academic Achievement?. Danish School of Education, Aarhus University, Tuborgvej 164, DK2400 Copenhagen NV, Denmark. Purwanto, Ngalim. 2007. IImu Pendidikan Teoretis dan Praktis. Bandung: PT Remaja Rosdakarya, p.11, p.80.

Sabri, M. Alisuf. 1999. IImu Pendidikan. Jakarta: CV Pedoman IImu Jaya. Setiawan, 2006. Meraih Nilai Akademik Maksimal. Jakarta. 
Sobur, 2006. Psikologi Umum. Bandung: Pustaka Setia.

Soetipto dan Raflis Kosasi, 2004. Profesi Keguruan. Jakarta: PT Rineka Cipta.

Sumardiono, 2007. Homescholling $A$ Leap for Better Learning: Lompatan Cara Belajar. Jakarta: PT Elex Media Komputindo.

Supramono dan Sugeng W. Hartono, 2005. Kesediaan Orang Tua Mengalokasikan Biaya Pendidikan, Pendapatan dan Tingkat Pendidikan Orang Tua Desa Oelbubuk dan Hubungannya dengan Aspirasi Anak Melanjutkan Sekolah, Jurnal Kependidikan, Vol. 6 No. 1, Juni.

Suryabrata,S., 2006. Psikologi pendidikan. Jakarta: PT Raja Grafindo Persada.

Suryadi, Ace. 1999. Pendidikan Investasi Sumber Daya Manusia dan Pembangunan: isu, teori dan aplikasi. Jakarta: Balai Pustaka.
Suryosubroto, 1990. Beberapa Aspek Dasar-Dasar Kependidikan. Jakarta: Bina Aksara.

Susetyo, Benny. 2005. Politik Pendidikan Penguasa. Yogyakarta: PT LKIS Pelangi Aksara.

Taylor, S. \& Yu, D, 2008. The Importance of Socio-economic Status in Determining Educational Achievement in South Africa. South Africa : Development Policy Research Unit University of Capetown.

Thantawy R, 2004. Karakteristik Budaya Belajar Mahasiswa Yang Berprestasi Unggul. Jurnal IImu Pendidikan Parameter, No.18 Tahun XXI, Januari.

Tirtarahardja, Umar. 2005. Pengantar Pendidikan Edisi Revisi. Jakarta: PT Rineka Cipta. 